IFN Working Paper No. 1152, 2017

\title{
The Market-Promoting and Market-Preserving Role of Social Trust in Reforms of Policies and Institutions
}

Niclas Berggren and Christian Bjørnskov 
The Market-Promoting and Market-Preserving Role of Social Trust in Reforms of Policies and Institutions*

\author{
Niclas Berggren $^{\perp}$ and Christian Bjørnskov ${ }^{\Delta}$
}

Abstract: Social trust has been identified as a catalyst for reforms. We take the literature further in two ways. First, we make a fine-grained analysis of mechanisms through which social trust enables liberalizing reforms - by strengthening the ability to overcome obstacles in the political process (stemming from ideology, ideological fractionalization, coalition government, minority government and legislature-seat instability). Second, we define reforms as distinct changes in the quality of the legal institutions and in the scope of regulation and separate reforms that increase economic freedom in these two areas from reforms that

\footnotetext{
* The authors wish to thank Andreas Ek, Shaomeng Jia and Joe Rieff, as well as conference participants at the 2016 Public Choice Society meeting in Fort Lauderdale, the 2016 European Association of Law and Economics meeting in Bologna and the 2016 Southern Economic Association meeting in Washington, DC, for helpful comments and suggestions, and the Jan Wallander and Tom Hedelius Foundation (Bjørnskov), the Swedish Research Council (Berggren), Torsten Söderbergs stiftelse (Berggren) and the Czech Science Foundation (GA ČR, grant No. 16-19934S) (Berggren) for financial support. $\perp$ Research Institute of Industrial Economics (IFN), Box 55665, SE-102 15 Stockholm, Sweden; and Department of Institutional, Environmental and Experimental Economics (KIE), University of Economics in Prague, Czech Republic. niclas.berggren@ifn.se.

$\Delta$ Department of Economics and Business, Aarhus University, Fuglesangs Allé 4, DK-8210 Aarhus V, Denmark; and Research Institute of Industrial Economics (IFN), Sweden. chbj@econ.au.dk. Corresponding author.
} 
decrease it. We study separately how social trust, interacted with the different types of political hindrances, affects the probability of reforms. We find a dual role of social trust in the political process - facilitating liberalizing reforms and making de-liberalizing ones more difficult. This result suggests that trust does not make agreement on any reform more probable - the content of the reform matters. Other research shows that trust is associated with a positive view of market actors, which indicates that only reforms that strengthen the market economy are more easily agreed upon in the presence of trust.

JEL Classification: H11, P11, P48, Z13

\section{Introduction}

Since the early 1980s, a consensus has formed among economists and political scientists that institutions and basic economic policies are central determinants of long-run economic growth and development (Aron, 2000; Rodrik et al., 2004; Acemoglu et al., 2005). ${ }^{1}$ Hence, if one cares about growth rates, the question becomes how to make the design and successful implementation of reforms that increase growth more probable and make reforms that decrease it less probable. Clearly, there are obstacles to reform - it is often hard to reach

1 Early surveys (Berggren, 2003; de Haan et al., 2006) and subsequent studies (e.g., Williamson and Mathers, 2011; Rode and Coll, 2012) indicate that the degree to which institutions and policies are market-oriented, as measured by the Economic Freedom of the World (EFW) index, is positively related to growth rates. 
agreement among political decision-makers in the presence of diverging preferences and characteristics of the political setting. But since reforms can be either good or bad for growth, some obstacles to agreement may consequently be seen as bad and others as good. Is there a way to reduce the power of the former obstacles while increasing the power of the latter? That is the topic of this study.

To answer this question, we build on insights that began to be rediscovered by economists and political scientists during the 1990s, to the effect that culture and the broader social fabric are important factors behind both institutions and economic outcomes (Knack and Keefer, 1997; Uslaner, 2002; Guiso et al., 2006; Algan and Cahuc, 2014; Alesina and Giuliano, 2015; Gorodnichenko and Roland, forthcoming). Not least, one cultural characteristic, social trust, has been shown to matter. By "social trust" is meant an attitude towards people you do not know or know very little about: it is based on an expectation that others - people in general - will do well by you in social interaction and not exploit you. ${ }^{2}$

Hence, we join a growing literature that investigates how certain features of the political landscape affect the probability of institutional and policy reform - and how social trust can interact with these features to make reforms more or less likely. ${ }^{3}$ For reforms to take

2 Social trust is sometimes referred to as generalized trust. It differs from two other types of trust: particularized trust, which refers to trust in people one knows or knows something about, and institutional trust, which refers to trust in organizations (mostly political ones, such as the central bank, government and political parties).

3 See, e.g., Boix and Posner (1998), Heinemann and Tanz (2008), Pinotti (2012), Berggren et al. (2014, 2016), Leibrecht and Pitlik (2015) and Pitlik and Kouba (2015). To the reform studies, one can add Bloom et al. (2012), who show that trust enables delegation of 
place, substantial agreement among policymakers is needed, and since trust involves an expectation that others will not behave opportunistically, it is to be expected that trust will enhance the chances for reforms to come about. For example, Boix and Posner (1998) hypothesize that social trust alleviates the coordination problems associated with gaining consensus. If politicians and potentially adversarial political groups share a basic trust in each other, a reform can be negotiated in which some partners are given a credible promise of a benefit in future negotiations if they perceive that they or their core constituency may lose from the reform in question. Some level of trust therefore allows inter-temporal log-rolling, which in turn enables agreement "here and now" to do something. ${ }^{4}$

Our contribution consists of looking at how five types of potential obstacles to political agreement - ideology, ideological fractionalization, coalition government, minority government and representational instability - affect the probability of reform and how social trust influences their effects. We define institutional and policy reform as a substantial change in one of two areas of the Economic Freedom of the World index: the quality of the legal system (an institutional indicator) and the scope of regulation (a policy indicator).

Importantly, we separate reforms that increase economic freedom (i.e., improve the quality of the legal system or reduce the scope of regulation) from reforms that decrease it. This

responsibility in private firms, a result that generalizes to most developed countries (Gur and Bjørnskov, 2016).

${ }^{4}$ We study social trust because it encompasses a comprehensive set of groups of people, like politicians, interest groups and voters. This means that it applies to "all" groups without any particular differentiation, unlike measures of particularized trust, which look at trust in particular organizations. In addition, while trust in, e.g., the political system or specific government institutions can vary considerably over time, social trust tends to be very stable. 
distinction is an innovation in the literature. As such, we focus on the extensive margin, i.e., whether such substantial reforms are likely to occur or not, and not the intensive margin in the form of the size or scope of the reform.

Our empirical analysis first reveals, as expected, that the various obstacles make any type of reform, both those bringing about liberalization and those bringing about deliberalization, less likely. However, an interesting pattern emerges: a dual role of social trust, in that it, by interacting with the different obstacles, facilitates certain reforms - those that entail liberalization - but makes others - reforms that reduce market liberalization - more difficult. In other words, social trust is not content-neutral in affecting how various obstacles to reform affect reform likelihood - it seems to both promote and protect market-oriented institutions and policies.

Why so? One could have expected, based on the prior literature, that social trust would make any reform more likely. Our hypothesis for why this is not so is that social trust not only facilitates agreement in general among political decision-makers, which is the important reason for expecting it to stimulate reform, but that it also entails trust in market actors. In fact, Aghion et al. (2010) find that people who trust people in general are more likely to associate the market economy with favourable outcomes. For this reason, we suggest that people with high social trust will be inclined to agree on market-friendly reforms and to disagree about reforms that reduce the scope of the market.

In the following, we present our theoretical perspective (Section 2), our data (Section 3), our empirical results (Section 4) and our concluding remarks (Section 5). 


\section{Theoretical considerations}

In the following, we consider what makes reforms more or less likely. Our simple starting point is that reforms are the result of actions undertaken by legislators in the political process. For a legislator to consider a reform desirable, he or she needs to find that a goal of some kind is better achieved through reform than the status quo. For reforms to come about, a majority needs to form in which a sufficient number of legislators agree that reforms are desirable and should be implemented. However, agreement is rarely a trivial matter in politics. Many politicians may not want reform; and among those who do, opinions may very well differ as to what kind of reform to implement. Different attitudes to reform stem either from different preferences, different beliefs (about what measures that best satisfy preferences) or both.

When it comes to preferences, political behaviour may be guided by "altruistic" motives such as a wish to maximize social welfare in society, where the behaviour arises from politicians with generalized morality (Tabellini, 2008), or it may be guided by "selfish" motives such as a wish to maximize the own income stream or personal power. Selfish motives may, however, induce a politician to act in a way that benefits social welfare, when he or she is incentivized to mimic a concern for the welfare of people in general, e.g., in order to win elections and retain voter support (Boix and Posner, 1998). Selfish motives may likewise induce politicians to mimic being trustworthy if civic voters apply a 'moral yardstick' to judge their behaviour (Bjørnskov, 2010). Irrespective of whether the preferences are altruistic or selfish, political power is needed to implement political programs, and for that reason, the politician needs votes in elections. But even though a politician necessarily 
cares about getting a large number of votes, he or she can also pay attention to interest groups although the policies they advocate are disliked by many voters (Buchanan and Tullock, 1962). This follows since interest groups can be aligned with the politician's own policy preferences, can offer valuable support in elections so that more votes can be gained and can provide private material net benefits (which are interesting to "selfish" politicians). ${ }^{5}$ In line with Peltzman (1976), there is thus a trade-off, in which reforms are undertaken, between satisfying voters and interest groups.

In this setting, where power is the intermediate goal (for some underlying reason), it is a matter of belief about the likely consequences of specific policies whether some reform will be a useful tool for better reaching it. As we will argue below, both goals and beliefs will be affected by social trust, and so we expect systematic differences in reform propensity between a low- and a high trust society.

In addition to these "internal" considerations of the politicians, there are "external" factors to take into account: most notably characteristics of the actual political setting. By this is meant such things as ideology, ideological fractionalization in the legislature, whether the government is supported by a majority or not in the legislature and whether the government consists of a single party or a coalition. For a given set of preferences and beliefs among politicians, these factors influence the probability of reaching political agreement and therefore the probability of reform. If there is fractionalization, coalitions and minority governments etc., more bargaining is generally needed before reform decisions can be taken

5 We talk in the following of "net benefits", which should be interpreted in welfarist terms. 
- if they can be taken at all. Also here, we argue that social trust is a relevant influence on the ability to overcome these obstacles to agreement.

The starting point of our analysis is thus a setting with three groups of actors: politicians, voters and interest groups. These actors are assumed to be active in one of two types of society: either a low-trust or a high-trust one. The two types of setting potentially differ in important respects, as a result of the different levels of social trust. Most notably, they differ in some respects with regard to preferences (or goals), with regard to beliefs and with regard to the ability to overcome "external" obstacles to agreement among politicians. ${ }^{6}$ We summarize the main differences in Table 1.

Beginning with preferences, the low-trust setting entails a more selfish kind of politician, who will try to use his or her position for personal benefit. ${ }^{7}$ This does not mean that there is no concern for aggregate net benefits, but the more important thing is to secure personal net benefits. The high-trust setting, on the other hand, either comes with politicians of the more altruistic kind, who sympathize with broad groups of people in general and want them to do as well as possible, or with selfish politicians. However, in the latter case, they

\footnotetext{
${ }^{6}$ With regard to the preferences of the voters and interest groups, we assume that they are the same in both settings: the former want as high aggregate net benefits (broadly interpreted) as possible; the latter want as high net benefits (broadly interpreted) for their particular groups as possible.

${ }^{7}$ Our assumption of low trust being associated with more selfishness has empirical support. For example, Kanagaretnam et al. (2009) show experimentally that there is a positive relationship between trust and social value orientation (a measure of other-regarding preferences), and Fehr (2009) finds a positive relationship between a survey indicator of altruism (volunteering) and trust.
} 
will tend to act as if they are altruistically motivated, since the high-trust setting comes with more "civic" voters with a different moral yardstick, who are more likely to react to what they perceive as immoral or dishonest behaviour. The voters expect the politicians to act in their interest, and if they do not, they will hold them accountable and withdraw their support, which will induce better behaviour even by selfishly motivated politicians in a high-trust society (Boix and Posner, 1998; Bjørnskov, 2010).

In addition to possibly different maximands between the low- and high trust settings, there is another preference-based difference: the degree of patience. Low-trust people do not take a long time perspective into account - as trust is needed to "wait out" good long-term effects - whereas high-trust people are able and willing to let the processes work, e.g., after a reform, in the expectation that good outcomes will dominate in the end (Almond and Verba, 1963; Putnam, 1993).

As for interpersonal beliefs, in low-trust settings actors regard others with suspicion: they fear opportunism and exploitation (Uslaner, 2002). This extends to the market, where there is distrust of economic actors. ${ }^{8}$ High-trust people, in contrast, expect the market actors to behave well and benefit people in general (even though these actors may only strive for personal gain). In addition, if the reform entails J-curve adaption such that the short-run net benefits for one or more groups are negative, a high-trust environment is more likely to enable voters and special interests to believe that the longer-run net benefits will be positive

8 Aghion et al. (2010) document an empirical relationship between having low social trust and these three attitudes towards the market economy: "Competition is harmful", "The government should take more responsibility" and "In democracy, the economic system runs necessarily badly". 
despite the observably negative immediate effects (Pitlik and Kouba, 2015). In other words, Tullock's (1975) “transitional gains trap" is a less binding constraint in reform processes in high-trust societies.

Lastly, the ability to overcome obstacles in the political process is low without trust and high with trust. This is really a function of beliefs as well: the interpersonal beliefs of politicians, voters and interest groups that "the others" can be trusted to want net benefits for all, to not exploit others, to stick to their word, to be patient and wait for long-term effects, etc. If such expectations are in place - as explained by, e.g., Boix and Posner (1998), Heinemann and Tanz (2008), Berggren et al. (2014) and Leibrecht and Pitlik (2015) obstacles to agreement will more easily be overcome.

\section{Insert Table 1 about here}

To illustrate our reasoning, we make use of Fig. 1. Let "economic freedom" refer to the degree to which institutions and policies are market-oriented. A liberalizing reform moves the status quo to the right in the figure, and a de-liberalizing reform moves the status quo to the left. There are three curves. The upwards-sloping, hyphenated curve denotes the true aggregate net benefits and also the subjective aggregate net benefits when people (both politicians and voters) are trusting, as a function of economic freedom. That is, their expectations are factually correct. The fully drawn down-sloping line denotes the subjective aggregate net benefits with low trust (among both politicians and voters). This relates to the beliefs mentioned in Table 1 - low-trust people expect more market orientation to be detrimental to people in general. The dotted down-sloping line denotes the true and subjective net benefits for the major interest group (think of it as a labour union, a monopoly firm or a 
sector protected from international competition) that benefits from more regulation or the like. This interest group knows how it is affected by liberalizing reform.

\section{Insert Figure 1 about here}

Assume that the status quo is at A, with comparatively low economic freedom. A liberalizing reform, going from A to B, would increase aggregate net benefits but reduce the net benefits of the interest group. In a high-trust setting, politicians and voters perceive this situation correctly, and since politicians are oriented towards maximizing aggregate net benefits, either due to having other-regarding preferences or by being held accountable by civic voters, they will be inclined to pursue the reform, with the support of voters. Interestingly, if the status quo is at B and a reform going to $\mathrm{A}$ is considered, neither politicians nor voters would favour it.

We thus see that social trust is not, as has often been argued in the previous literature, facilitating any reform but only reforms that increase economic freedom - the main reason being the belief with high trust, that a stronger market orientation entailing higher aggregate net benefits (Aghion et al., 2010). The role of social trust in the reform process is dual in that sense: it facilitates certain reforms but make others less probable.

If we instead look at a low-trust setting, going from A to B will be resisted, as both politicians and voters believe such a reform would reduce aggregate net benefits. In addition, the interest groups that the politicians interact with would also lose out on such a move, and therefore no such reform will be forthcoming. On the other hand, a reform from B to A would be supported. The overall insight so far is that social trust transforms the thinking of people in the political process in a way that affects the probability of liberalizing and de-liberalizing reform. 
The reasoning above has focused on what the politicians want, or do not want, to do in stylized settings with low or high social trust and what voters are likely to accept, but with virtually no political transaction costs. However, willingness to undertake reform is one thing, an ability to do so in real political systems another. As has been noted, there may be obstacles to actually agreeing on reform due to characteristics of the political setting - and of the reforms as such (see, e.g., Tullock, 1975). Social trust is highly relevant here as well, by potentially alleviating "frictions" of various kinds and by creating expectations of good behaviour over time. In the following, we consider some of these characteristics of the political setting and reforms, as well as the role social trust might play for making reforms more or less probable.

We begin with ideology. The usual pattern in democracies is to have parties to the right and parties to the left (with some in between in the centre as well). One might imagine that politicians in parties on the right will tend to favour liberalizing reforms and politicians on the left to favour de-liberalizing reforms (cf., Besley and Case, 2003). However, this is not necessarily the case. Some parties on the right, especially more conservative ones, are often market sceptics, while some parties on the left have been key actors in deregulation and tax reforms. We argue that social trust will tend to make liberalizing reforms more probable, and make de-liberalizing reforms less probable, for politicians who have an ideologically based pessimistic view of human motivation and capacity. For example, politicians on the left may believe that regulation is necessary to stifle companies that would otherwise only consider enriching themselves at the expense of their employees and the broader society, reducing aggregate net benefits. 
If, all else equal, politicians and voters become more trusting, they will regard this risk as smaller and be more prone to undertake liberalizing reform; a reinforcing effect comes from a change in preferences, such that interest group considerations (of a pro-regulation kind) also become less prominent in their decision function. In addition, politicians will need to communicate to their constituency that reforms are necessary. As realized by Cukierman and Tomassi (1998), left-wing parties may be better able to communicate credibly because they are known a priori to be against liberalization. We argue that such "Nixon goes to China" effects are more likely to occur in societies with higher levels of social trust.

Next consider coalition government. A government that consists of many parties is typically based on bargaining and log-rolling to balance their different interests. ${ }^{9}$ Compared to single-party governments coalitions therefore tend to make agreement more difficult, as different preferences and interpersonal beliefs are present in the executive body of the polity. These are moved in a reform-friendly direction in the presence of social trust, as negotiations will be facilitated by a higher congruence in preferences and beliefs (in a market-friendly direction) and by an expectation that the coalition partners will stand by their word, not exploit weak parts of any agreement, and not renege on their promises once the political situation changes. Naturally, single-party governments can also benefit from social trust, to the extent that there is internal dissent - which may be especially relevant in the case of parties on the left that are pondering liberalizing reforms or why not to de-liberalize - and to the extent that there must still be negotiations with other parties and with key interest groups. Moreover, research indicates that social trust can limit rent-seeking-based reforms that are

\footnotetext{
${ }^{9}$ Persson and Tabellini (2004) argue that this is a feature typical of proportional electoral systems.
} 
not in the public interest (Bjørnskov, 2010). This mainly occurs because voters are able to observe or infer which politicians and political parties are associated with rent-seeking behaviour, and high-trust voters are sufficiently civic to strongly punish the specific actors engaged in it. While coalition governments thus must rely on negotiations that could be facilitated by social trust, their structure also implies that the specific rent-seeking actors are difficult to observe. As such, the voter mechanism may be stronger with single-party governments that cannot "hide" in the sense of blaming coalition partners or other parties entering a reform agreement, implying that the effects of social trust in limiting reforms stemming from rent-seeking may in fact be greater in the case of single-party governments. So the more trust, the more there is a move of decision-makers to adopt, as their outlook, the positive-sloping curve in Fig. 1, both if they are in coalition and single-party governments. Another characteristic of many political settings is minority government. Such a government usually has to negotiate with other parties in the legislature to get any proposal accepted, and also here, social trust should make agreements about liberalizing reforms, and resistance to de-liberalizing reforms, easier, by affecting preferences and beliefs in line with Table 1. It may also be easier for minority governments to communicate credibly when reforms take a particular form not preferred by their core voters as a result of negotiations to secure a majority. Majority governments too can benefit, however, especially if one views the political game as an intertemporal one. No government is assured of power in the future in a democracy, and to ensure desired outcomes, it is often desirable to try to anchor reforms in the present minority - which becomes easier with trust. In addition, similar problems with observing who is responsible for particular policy decisions as with coalitions may apply to minority governments, which makes it "easier" for trusting voters to punish parties or 
politicians catering to rent-seekers with majority governments. This in turn suggests that the positive effect of trust on the probability of such governments undertaking pro-market reforms may be strong, and possibly even stronger than for minority governments.

In addition, ideological fractionalization in the legislature may stifle liberalizing reform efforts, as preferences are more widely dispersed. If there is social trust, it will be easier for parties across ideological lines to see matters in a similar way and to not think that the other side is out to destroy them or weaken their key constituencies. It will also be easier to resist attempts to de-liberalize, if there is less distrust of market actors, not least, and if there is a reduced willingness to give interest groups a strong say in the political process. As argued by Bjørnskov (2010), voters may also be less willing to accept outright interest-group influence in high-trust environments and hold politicians accountable.

We next turn to seat instability. This factor points at the risk that increased uncertainty about future power makes politicians less inclined to undertake reforms, whose effects may be undermined by new politicians coming into power with different agendas. With trust there is less suspicion that this will happen over time, and hence this will reduce the perceived risk for reforms being undermined. This will in turn make reforms more probable (although, as the distrust of market actors weakens, not de-liberalizing ones). ${ }^{10}$ Additionally, another way of ensuring the political viability of reforms after the next election may be to secure a supermajority for the reforms that exacerbate the political logrolling problem, which we argue is alleviated by social trust (Groseclose and Snyder, 1996). Yet, to

\footnotetext{
${ }^{10}$ There is a possibility for an offsetting effect of seat instability: by reducing incumbency advantage, the instability may involve the removal of politicians who block reform, e.g., due to interest-group capture. It is an empirical issue which effect dominates.
} 
secure a supermajority in order to stabilize reforms simply exacerbates the political negotiation problem, which then increases the potential returns to trust.

Lastly, let us look at the characteristics of reforms. Reforms may differ in many ways, e.g., firstly, if they refer to more basic institutions or policies and whether the benefits and costs are dispersed or concentrated, and secondly, if their effects manifest themselves rapidly or slowly, and if there are monotonic effects on aggregate net benefits or whether there are J-curve effects. These aspects as such are relevant for the probability of liberalizing or de-liberalizing reform, but they may also be affected by social trust. In particular, in situations where reform processes have identifiable distributional consequences - i.e., where special interests have specific reason to resist reforms that remove protection or other support (Tullock, 1975; Hillman, 1982; Leighton and López, 2013) - achieving a compromise may be especially difficult.

As for reform speed, this is particularly relevant with regard to elections. If there are J-curve effects that imply lower aggregate net benefits for some time after a reform, but higher such net benefits in the longer term, then this may dissuade politicians from undertaking reform, especially if an election is coming up in the short term. (Relating to Fig. 1 , the curves can be interpreted as being in denoted in "net present value" terms, and they thus hide possible J-curve effects.) This effect will be mitigated by social trust, however, in making the politician trust the voters to not punish him or her for temporary losses if there are credibly forthcoming gains. There is, in other words, more patience with high trust (cf. Almond and Verba, 1963). We also expect more market-friendly, trusting voters to be more prone to expect net benefits from liberalizing reform. In alignment with such an effect, an environment of trust also enables politicians to communicate more credibly to voters that the 
long-run effects of reforms will be beneficial in a situation where voters can observe the short-run costs.

To conclude our theoretical discussion, the preferences and interpersonal beliefs of politicians determine how willing they are to liberalize the economy, or to resist from deliberalizing it. Both of these factors are affected by social trust, so as to make liberalizing reform more probable and de-liberalizing reform less probable. In addition, features of the political setting and the reforms themselves affect the ability to pass a reform proposal. There are many obstacles in the political game, but also here, social trust can provide an attitude among the relevant decision-makers that make them take a social-welfare perspective, to not regard each other with suspicion and to expect markets to provide aggregate net benefits, the effect of which is to facilitate liberalizing and block de-liberalizing change. Similarly, social trust may make voters more prone to punish politicians at the next election if they perceive dishonest or rent-seeking behaviour and can identify or infer the specific politician or party to blame. While our overall thesis is that social trust affects the likelihood of observing reforms, in the following we test the more specific hypothesis that trust mainly affects this likelihood in conjunction with one of the five particular political problems outlined in this section.

\section{Data and empirical approach}

Most studies so far have employed the changes to policy and institutional indicators as proxies for reforms - that is, the measures used have been continuous and studies have not looked at different kinds of reforms. In this paper, we employ a somewhat different approach, 
which to a larger degree allows us to separate small changes from actual reforms and also allows for the separation of liberalizing and de-liberalizing reforms. We do so by creating two dummy variables measuring whether a large market-enhancing reform or a similarly large market-constraining reform took place within each of the five-year periods between 1975 and 2010 and associate it with various political obstacles to reform, with social trust and with a set of control variables. As such, we avoid the implicit assumption in previous studies that the effects of social trust are symmetrical across positive and negative changes. We also sidestep the implicit question of whether social trust facilitates larger reforms by exclusively focusing on the extensive margin.

Before turning to the specific variables, we need to briefly discuss the country sample. Our full sample is comprised of 67 countries that are either members of the OECD, similar to OECD members or situated in Latin America. We therefore exclude all countries in Africa, the Middle East, Asia and the Pacific, with the exception of five - Israel, Japan, Singapore, South Korea and Taiwan - that have stable political institutions similar to those in Europe and the Americas. We do so since the theoretical arguments in Section 2, and indeed the topic of this paper, presupposes the existence of either fully democratic political institutions or constitutionally democratic institutions modelled on European democracies. The countries we include fit that description by being either full democracies or having de iure political institutions embedded in formally democratic constitutions (even though not all are fully de facto democratic). 


\subsection{Institutional reform data}

The two indicators that we use to build the set of reform measures derive from the Economic Freedom of the World (EFW) index from the Fraser Institute (Gwartney et al., 2015), and concern the quality of the legal system and the degree of regulatory freedom. ${ }^{11} \mathrm{We}$ focus on these measures since the former is an institutional and the latter a policy indicator; and it will be interesting to see whether both are determined similarly by our explanatory variables. These measures have been used widely in economics and political science and are now considered one of the most reliable sources of institutional and economic policy differences (see Hall and Lawson, 2014, for a survey). Previous studies have also connected elements of economic freedom indices to social trust (e.g., La Porta et al., 1997; Berggren and Jordahl, 2006; Bjørnskov, 2010; Berggren et al., 2014, 2015; Robbins, 2012; Williamson and Rathers, 2011; Leibrecht and Pitlik, 2015; Pitlik and Kouba, 2015).

The particular reform dummies are created by separating the observations of period-toperiod changes into three groups of equal size: We give the relatively large positive changes the value 1 , the middle third of the observations the value 0 and the most negative changes the value -1 , which enables us to focus on the extensive margin of reforms. In the following, we separately estimate the determinants of observing positive and negative reforms, respectively. In this simple way, we are to some degree able to assess whether social trust

\footnotetext{
${ }^{11}$ Since the EFW measures economic freedom, which is inversely related to the scope of regulation, we use the term "regulatory freedom" to denote the inverse of the scope of regulation. This corresponds to area 5 of the EFW.
} 
affects the likelihood of liberalizing and de-liberalizing reforms differently and, by extension, how it influences the stability of market-promoting institutions. ${ }^{12}$

\subsection{Social trust}

We follow what has become standard in the literature by using the social trust question invented by Elisabeth Noelle-Neumann and popularized by the US General Social Survey: “In general, do you think most people can be trusted or can't you be too careful?". The trust scores are the percent of respondents in each country stating that most people can be trusted. This particular measure has been used extensively and shown to correlate with a number of behavioural characteristics of countries around the world. Knack and Keefer (1997) pioneered validity tests of the trust measure by noting that return rates in wallet-drop experiments around the world correlate strongly with survey trust (Felton, 2001; Bjørnskov, 2010). Further studies show that it is associated with behaviour in trust-sensitive economic experiments such as dictator and public goods games (Sapienza et al., 2007; Cox et al., 2009), with overall governance (Putnam, 1993; Knack, 2002; Bjørnskov, 2010; Robbins, 2012) and with environmental action (Sønderskov, 2008).

Several studies also suggest that trust scores are remarkably stable over time in most countries (Bjørnskov, 2007; Uslaner, 2008; Algan and Cahuc, 2010). To maximize the

\footnotetext{
${ }^{12}$ Over the period 1975-2010 in total, most countries have liberalized their economic policies and either strengthened or maintained the quality of their legal institutions. However, identifying positive and negative reforms relative to a sample trend instead of an absolute yields a very similar identification of the reforms. In the following, the general trend is also captured by the inclusion of a set of period dummies.
} 
number of observations, we therefore use the data on OECD countries, OECD-like countries and Latin America in Bjørnskov and Méon (2013), which are compiled by using all information in the six waves of the World Values Survey between 1981 and 2010, data from the 1995-2012 LatinoBarómetro, the 2002-2004 Danish Social Capital and recent observations from the LaPop surveys that cover Latin America and the Caribbean.

\subsection{Measures of political obstacles to agreement}

For social trust to affect the likelihood of reforms, it must interact with some form of political obstacle to agreement, either making agreement more or less easy to achieve. As noted above, we focus on problems associated with gaining stable majorities deriving from ideological differences or structural problems (such as minority and coalition government).

To build proxies for such obstacles to agreement, we first define government ideology as $G I=\sum_{i=1}^{m} p_{i} s_{i} / s_{g}$, where $p_{i}$ is the ideological position of party $i, s_{i}$ is the seat share in the legislature of party $i, m$ is the number of parties in the government coalition and $s_{g}$ is the combined seat share of government parties in the legislature. Legislature ideology is defined similarly as $L I=\sum_{i=1}^{n} p_{i} s_{i}$, where $n$ is the number of parties represented in the legislature. Ideological fractionalization in the legislature is $L F=\sum_{i=1}^{n}\left(p_{i}-P I\right)^{2} s_{i}$, and ideological fractionalization in government is $G F=\sum_{i=1}^{m}\left(p_{i}-G I\right)^{2} s_{i}$. These data are all in turn based on our coding of all parties on a scale from -1 to $1 .^{13}$ The values of government ideology GI can

\footnotetext{
${ }^{13}$ The specific coding follows the general approach in Bjørnskov and Potrafke (2012). The position of unreformed socialist parties are coded at -1 , reformed and moderate socialist parties at -0.5 , social democratic parties at 0 , conservative parties at 0.5 , and parties with some basis in classical liberalism at 1 . All detailed party data are available upon request.
} 
therefore be interpreted as for example corresponding to -0.5 (modern socialist), 0 (modern social democrat), 0.25 (conservative-social democrat coalition), 0.5 (conservative) and 0.75 (conservative/classical liberal coalition).

To proxy for structural, non-ideological problems, we code dummies for minority governments and multi-party coalition governments, as well as a measure of the stability of the party structure. While the minority dummy directly captures situations in which a government must always negotiate to find support, or at least not opposition, from other parties to get proposals passed through the legislature, coalition government instead captures situations in which such negotiation necessarily mainly occur within government, regardless of whether they reflect minority or majority positions. Finally, we proxy political/party stability by calculating the share of all seats in the legislature that were lost/won by any party in the previous election.

A first question to ask is to which degree the political conditions - ideology, coalition and minority status - can be statistically and conceptually separated. The structure of the data suggests that any conceptual and actual distinction should be relatively unproblematic. Approximately half of the sample has had coalition governments and about a fourth of incumbent governments have been in minority. Yet, the overlap is relatively small as a third of coalition governments have also been in minority while two thirds of the minority governments have been coalitions. The only significant overlap in terms of political circumstances is that almost 90 percent of all governments to the right of the middle have been coalitions between more than one party.

The way we attempt to empirically identify the political conditions under which social trust are more or less important is to interact trust with ideology, ideological fractionalization, 
the dummies for minority and coalition government and the stability measure. In order to interpret these effects, we provide marginal effects evaluated with conditional marginal standard errors calculated by the delta method (Brambor et al., 2006). In a lower panel of each regression table, we provide marginal effects of social trust evaluated at different values of each political obstacle.

\subsection{Control variables}

We add a number of control variables often found in the recent reform literature. We first add the lagged level of the economic freedom index for which we are estimating reform likelihood. We also add the logarithm to population size and real GDP per capita, as larger and more developed economies may be characterized by a larger number of potentially more entrenched special interest groups with an interest in the status quo (Olson, 1982). However, richer countries also tend to have better bureaucracies and thus superior implementation. Open economies, on the other hand, tend to have better governance and less corruption (cf. Rodrik et al., 2004), which is why we include an indicator of economic openness, trade volumes as percent of GDP. These data are from Heston et al. (2012). In addition, we add dummies for presidential democracy, civil autocracy and military dictatorships based on the categorization in Cheibub et al. (2010). We summarize all these variables in Table 2.

Insert Table 2 about here

\subsection{Empirical approach}

We have a maximum sample of 442 observations in the seven five-year periods beginning in 1975 and ending in 2010. In the following, we present the results of a set of random effects 
logit regressions. Using a random effects estimator in this type of panel data is a necessary choice since social trust scores are approximately time-invariant, which in this setting precludes the use of any fixed effects estimator (Bjørnskov, 2007). ${ }^{14}$ We nevertheless add a full set of period fixed effects and regional fixed effects covering post-communist countries, South East Asia and Latin America.

More precisely, we estimate equation (1), where $\mathrm{R}$ is either a liberalizing or deliberalizing reform, $\mathrm{X}$ is a vector of control variables, $\mathrm{I}$ is a vector of political obstacles as outlined above, $\mathrm{T}$ is social trust, I' is an element of the I-vector which we interact with trust, $\mathrm{D}$ is a vector of period and regional fixed effects, and $\varepsilon$ and $v$ are error terms. The I-vector always includes minority and coalition government and one of the four additional measures of political obstacles.

$$
\operatorname{Prob}(\mathrm{R})=\alpha+\beta \mathrm{X}+\gamma \mathrm{I}+\delta \mathrm{T}+\mu \mathrm{I}^{\prime} \mathrm{T}+\eta \mathrm{D}+\varepsilon+v
$$

With all interactions, we add a bottom panel where we provide the conditional point estimate of trust along with its conditional standard error, evaluated at the $10^{\text {th }}$ and $25^{\text {th }}$ percentiles, the median and the $75^{\text {th }}$ and $90^{\text {th }}$ percentiles of the cross-country distribution of each continuous political obstacle variable (cf. Brambor et al., 2006); with coalition and minority government, we provide marginal effects for regimes with and without these characteristics.

14 In addition, it is well-known that the logit fixed effects estimator is inconsistent in the presence of serial correlation and heteroskedasticity (Wooldridge, 2010). Both problems are likely to be present in our data. 


\section{Empirical results}

In order to gain a first impression of the structure of the data, Fig. 2 plots the ratio of positive to negative reforms for area 2 of the EFW, measuring legal quality, comparing the high and low-trust halves of the sample, both separated in groups with and without coalition government. As illustrated in the figure, with single-party governments, the ratio of positive to negative reforms is 0.94 in the low-trust group and 1.14 in the high-trust group; conversely, with a coalition government, the ratios are 1.11 and 1.24.

\section{Insert Figure 2 about here}

The figure thus clearly illustrates that positive reforms are significantly more likely in the high trust group, and more likely among coalition governments. However, there may be other factors related to trust that differ between high- and low trust countries and that drive these results. For example, GDP per capita, initial institutional quality levels, government spending and the efficiency of special interests. We try to account for such other factors in the ensuing empirical analyses. We now present findings for the various potential obstacles to reform: ideological conflict, minority and coalition government and instability of the political system.

We present our regression results in Tables $3-5$. Table 3 is more detailed than the remaining ones in order to show our full baseline model specification, with all control variables included; the other ones present the estimates for our main variables of interest in order to conserve space but are based on full baseline model specifications as well.

\section{Insert Tables 3-5 about here}

Let us begin by commenting on the control variables. We first note that we find a smaller likelihood of positive reforms with higher initial values of the two areas of economic 
freedom under study, indicating a potential effect of reduced reform need. Yet, we also find a higher likelihood of negative reforms when initial index values are higher. In addition, we find larger probabilities of positive reform chances and substantially smaller probabilities of negative reforms in the legal area in richer countries, smaller reform chances in the regulatory area in presidential political systems but also a significantly smaller probability of negative reforms in legal quality in such systems. The final robust results among the control variables are the lower likelihood of negative reforms in the regulatory area from openness and a greater probability of reforms increasing regulation among minority governments.

Turning to the results involving our six "obstacle" variables and social trust, we report estimates of these and an interaction term in the tables. However, to get a clear grasp of what these findings substantially mean, we provide conditional trust effects evaluated at different percentiles of each "obstacle variable" at the bottom of Tables 3-5. We comment on four cases of calculations, looking at both types of reform (judicial or regulatory) and whether reform is positive or negative.

If we begin with the probability of reforms that increase the quality of the legal system, we find that it is positively related to social trust in a statistically significant manner at the average of each of the six "obstacle" variables: government ideology (reported in Table 3); legislator ideology, ideology fractionalization, seat instability, minority government, and coalition government (all in Table 4a). Overall, then, it seems as if this kind of institutional reform, strengthening the underpinnings of a market-based order, becomes more probable the more people trust each other. Yet, the effects of trust are small and insignificant in particularly left-wing and fractionalized polities and increasing in both government and legislature right-wing ideology and ideological fractionalization. 
Next, what about the probability of reforms that increase regulatory freedom? In this case, as can be seen in Table 3 and Table $4 \mathrm{~b}$, we only find that social trust matters in a significant way for one of the "obstacle" variables: minority government. When such a government is in place, social trust makes it more likely that policy reforms that decrease the scope of regulation take place. The sign is positive in the other five cases, but significance is not attained. Hence, social trust seems less potent as a stimulant of pro-market reform in the regulatory area, but when it does matter, it does facilitate reform (for minority governments).

If we then turn to the probability of reforms that decrease the quality of the legal system, we interestingly find that social trust is again negatively related to the probability of such reforms at the average value of each of the six "obstacle" variables (Tables 3, 5a). It makes such reforms less likely for all kinds of government and legislator ideology (except for clear left-wing cases); at all levels of ideological fractionalization; for both minority and majority governments, for both coalition and single-party governments and for all levels of seat instability. It seems as if social trust not only stimulates reforms that strengthen legal quality but that it also makes reforms that reduce it less likely.

Lastly, let us have a look at the probability of reforms that decrease regulatory freedom. As in the case of reforms that reduce the quality of the legal system, social trust turns out to have a "blocking" effect (Tables 3, 5b). It makes reforms of this kind less likely for all kinds of government and legislature ideology (except clearly left-wing cases); it reduces the likelihood of reform for median or higher degrees of ideological fractionalization; it does so in the case of minority and single-party governments; and for all but the highest level of seat instability. The overall pattern is such that social trust "protects" the market economy from more regulation. 
As a final question, we need to ask if the statistically significant findings are also of economic and political significance. In general, we find that they are of political relevance. The odds ratio associated with observing a reform that increases the quality of the legal system is approximately 1.05 , indicating that the increase in probability from a one-standard deviation trust difference (approximately 15 percent or about the trust difference between France and Germany) is almost 10 percentage points. With a clearly right-wing government, the difference increases to approximately 14 percentage points. The remaining significant findings imply quantitatively similar effect sizes, indicating that the effects of social trust on reform chances are worth discussing.

\section{Concluding remarks}

A growing literature since the seminal contributions of Putnam (1993), Knack and Keefer (1997) and La Porta et al. (1997) has documented a strong association between social trust and a set of institutions and policies. High-trust societies tend to have better judicial institutions, less market regulation and other growth-promoting economic policies in place. Yet, how they reached that status most often goes untested. The starting point of this paper is that there has typically been a reform process that has led to the establishment of judicial institutions and market-conforming regulation in spite of various potential obstacles. We propose, in line with a small, growing literature, that social trust has played a role in enabling reforms to come about. 
Our contribution is to examine how social trust interacts with a new set of potential obstacles to agreeing on reform - government and legislator ideology, ideological fractionalization, type of government (single-party/coalition and minority/majority, respectively) and legislature-seat fractionalization - to affect the probability of reform. We do this by looking at distinct changes in the quality of the legal system and the scope of regulation, thus sorting out small, continuous changes that can otherwise distort the study of explicit reforms. In that sense, we look at the extensive margin - whether large reforms occur and with what probability. Notably, we look separately at positive and negative changes to these two indicators of institutions and policies, in line with our theory, which suggests that social trust may not simply affect the probability of any reform but primarily of reforms that increase economic freedom (i.e., that increase the quality of the legal system and increase regulatory freedom). Not only that, social trust should also reduce the probability of reforms that reduce economic freedom. The basis for this prediction of a "dual" effect of social trust is that social trust entails confidence in the market economy (Aghion et al., 2010; cf. Pitlik and Kouba, 2015).

Our findings confirm our theoretical prediction: For both institutional (legal) reforms and policy (regulatory) reforms, social trust exerts an influence such that positive reforms become more likely and negative reforms less likely. This is especially clear for institutional reforms, where social trust interacts with center and right-wing ideology, almost all levels of ideological fractionalization, minority and majority governments, single-party and coalition governments and all levels of legislature-size fractionalization to make reforms that improve the legal system more likely and reforms that reduce the quality of this system less likely. In the case of regulatory reform, the pattern is similar but not present for all "obstacle" 
variables. Positive regulatory reform is more probable the stronger the level of social trust if there is a single-party government in place; for the other "obstacles" under study, the relation is positive but not significant. Negative regulatory reform is less probable the more people trust others (and, by implication, most actors in the market economy), for all our variables except minority and coalition governments.

Through our study, we have provided a clearer picture of what drives distinct reforms of key (legal) institutions and of an important policy area (regulation). The role of social trust has been confirmed, but its dual nature, in both stimulating reforms that increase economic freedom and hindering reforms that decrease it, is a novel result. We therefore contribute to the growing literature on how social trust affects the institutional framework of countries, as well as the conditions under which differences in trust are important determinants of differences in long-run development.

\section{References}

Acemoglu, D., S. Johnson, and J. A. Robinson. 2005. "Institutions as a Fundamental Cause of Long-Run Growth.” In Handbook of Economic Growth, vol. 1A, edited by P. Aghion, and S. N. Durlauf, 385-472. Amsterdam: Elsevier.

Aghion, P., Y. Algan, P. Cahuc, and A. Shleifer. 2010. "Regulation and Distrust." Quarterly Journal of Economics 125 (3): 1015-1049.

Alesina, A., and P. Giuliano. 2015. “Culture and Institutions.” Journal of Economic Literature 53 (4): 898-944. 
Algan, Y., and P. Cahuc. 2010. "Inherited Trust and Growth.” American Economic Review 100 (5): 2060-2092.

Algan, Y., and P. Cahuc. 2014. "Trust, Growth, and Well-Being: New Evidence and Policy Implications." In Handbook of Economic Growth, vol. 2A, edited by P. Aghion, and S. N. Durlauf, 49-120. Amsterdam: Elsevier.

Almond, G. A., and S. Verba. 1963. The Civic Culture: Political Attitudes and Democracy in Five Nations. London: Sage.

Aron, J. 2000. "Growth and Institutions: A Review of the Evidence.” World Bank Research Observer 15 (1): 99-135.

Berggren, N. 2003. "The Benefits of Economic Freedom: A Survey.” The Independent Review 8 (2): 193-211.

Berggren, N., S.-O. Daunfeldt, and J. Hellström. 2014. "Social Trust and Central-Bank Independence.” European Journal of Political Economy 34 (June): 425-439.

Berggren, N., S.-O. Daunfeldt, and J. Hellström. 2016. “Does Social Trust Speed Up Reforms? The Case of Central-Bank Independence.” Journal of Institutional Economics 12(2): 395-415.

Besley, T., and A. Case. 2003. "Political Institutions and Policy Choices: Evidence from the United States." Journal of Economic Literature 41 (1): 7-73.

Bjørnskov, C. 2007. "Determinants of Generalized Trust: A Cross-Country Comparison.” Public Choice 130 (1): 1-21.

Bjørnskov, C. 2010. “How Does Social Trust Lead to Better Governance? An Attempt to Separate Electoral and Bureaucratic Mechanisms." Public Choice 144 (1): 323-346. 
Bjørnskov, C. and N. Potrafke. 2012. "Political Ideology and Economic Freedom across Canadian Provinces.” Eastern Economic Journal 38 (2): 143-166.

Bjørnskov, C., and S. Voigt. 2014. "Constitutional Verbosity and Social Trust.” Public Choice 161 (1): 91-112.

Bloom, N., R. Sadun, and J. Van Reenen. 2012. "The Organization of Firms Across Countries.” Quarterly Journal of Economics 127 (4): 1663-1705.

Boix, C., and D. N. Posner. 1998. "Social Capital: Explaining Its Origins and Effects on Government Performance.” British Journal of Political Science 28 (4): 686-695.

Buchanan, J.M. and G. Tullock. 1962. The Calculus of Consent. Ann Arbor: University of Michigan Press.

Bortolotti, B., M. Fantini, and D. Siniscalco. 2004. "Privatisation Around the World: Evidence from Panel Data.” Journal of Public Economics 88 (1-2): 305-332.

Brambor, T., W. R. Clark, and M. Golder. 2006. "Understanding Interaction Models: Improving Empirical Analyses.” Political Analysis 14 (1): 63-82.

Cukierman, A., and M. Tommasi. 1998. "When Does It Take a Nixon to Go to China?" American Economic Review 88 (1): 180-197.

de Haan, J., S. Lundström, and J.-E. Sturm. 2006. "Market-Oriented Institutions and Policies and Economic Growth: A Critical Survey.” Journal of Economic Surveys 20 (2): 157191.

Fehr, E. 2009. "On the Economics and Biology of Trust." Journal of the European Economic Association 7 (2-3): 235-266.

Gorodnichenko, Y., and G. Roland. Forthcoming. "Culture, Institutions, and the Wealth of Nations." Review of Economics and Statistics. 
Groseclose, T., and J. M. Snyder, Jr. 1996. "Buying Supermajorities”. American Political Science Review 90 (2): 303-315.

Guiso, L., P. Sapienza, and L. Zingales. 2006. “Does Culture Affect Economic Outcomes?” Journal of Economic Perspectives 20 (2), 23-48.

Gur, N. and C. Bjørnskov. 2016. "Trust and Delegation: Theory and Evidence.” Forthcoming in Journal of Comparative Economics.

Gwartney, J. D., J. C. Hall, and R. A. Lawson. 2015. Economic Freedom of the World: 2015 Annual Report. Vancouver: The Fraser Institute.

Hall, J. C., and R. A. Lawson. 2014. "Economic Freedom of the World: An Accounting of the Literature." Contemporary Economic Policy 32 (1): 1-19.

Heinemann, F., and B. Tanz. 2008. "The Impact of Trust on Reforms." Journal of Economic Policy Reform 11 (3): 173-185.

Hillman, A. L. 1982. "Declining Industries and Political-Support Protectionist Motives.” American Economic Review 72 (5): 1180-1187.

Kanagaretnam, K., S. Mestelman, K. Nainara, and M. Shehataa. 2009. "The Impact of Social Value Orientation and Risk Attitudes on Trust and Reciprocity.” Journal of Economic Psychology 30 (3): 368-380.

Knack, S., and P. Keefer. 1997. "Does Social Capital Have an Economic Pay-Off? A CrossCountry Investigation.” Quarterly Journal of Economics 112 (4): 1251-1288.

Knack, S. 2002. "Social Capital and the Quality of Government: Evidence from the States." American Journal of Political Science 46 (4): 772-785.

La Porta, R., F. Lopez-de-Silanes, A. Shleifer, and R. Vishny. 1997. “Trust in Large Organizations.” American Economic Review 87 (2): 333-338. 
Leibrecht, M., and H. Pitlik. 2015. "Social Trust, Institutional and Political Constraints on the Executive and Deregulation of Markets.” European Journal of Political Economy 39 (September): 249-268.

Leighton, W. A., and E. J. López. 2013. Madmen, Intellectuals, and Academic Scribblers: The Economic Engine of Political Change. Stanford: Stanford University Press. Nannestad, P. 2008. "What Have We Learned about Generalized Trust, If Anything?” Annual Review of Political Science 11: 413-436.

Pinotti, P. 2012. "Trust, Regulation and Market Failures.” Review of Economics and Statistics 94 (3): 650-658.

Pitlik, H., and L. Kouba. 2015. "Does Social Distrust Always Lead to a Stronger Support for Government Intervention?” Public Choice 163 (3): 355-377.

Putnam, R. 1993. Making Democracy Work. Princeton, NJ: Princeton University Press.

Robbins, B. 2012. “Institutional Quality and Generalized Trust: A Nonrecursive Causal Model.” Social Indicators Research 107 (2): 235-258.

Rode, M., and S. Coll. 2012. "Economic Freedom and Growth: Which Policies Matter the Most?" Constitutional Political Economy 23 (2): 95-133.

Rodrik, D., A. Subramanian, and F. Trebbi. 2004. "Institutions Rule: The Primacy of Institutions Over Geography and Integration in Economic Development.” Journal of Economic Growth 9 (2): 131-165.

Sobel, R. S. and C. Coyne. 2011. "Cointegrating Institutions: The Time-Series Properties of Country Institutional Measures.” Journal of Law and Economics 54 (1): 111-134.

Sønderskov, K. M. 2008. "Environmental Group Membership, Collective Action and Generalised Trust." Environmental Politics 17 (1): 78-94. 
Tabellini, G. 2008. "Institutions and Culture." Journal of the European Economic Association 6 (2-3): 255-294.

Tullock, G. 1975. “The Transitional Gains Trap.” Bell Journal of Economics 6 (2): 671-678.

Tullock, G. 1981. “Why So Much Stability?” Public Choice 37 (2): 189-205.

Uslaner, E. M. 2002. The Moral Foundations of Trust. Cambridge: Cambridge University Press.

Uslaner, E. M. 2008. "Where You Stand Depends Upon Where Your Grandparents Sat: The Inheritability of Generalized Trust.” Public Opinion Quarterly 72 (4): 725-750.

Williamson, C. R., and R. L. Matters. 2011. "Economic Freedom, Culture, and Growth." Public Choice 148 (3): 313-335.

Wooldridge, J. M. 2010. Econometric Analysis of Cross Section and Panel Data, $2^{\text {nd }}$ Edition. Cambridge, MA: The MIT Press. 
Table 1. Political differences between low- and high-trust settings

Low trust High trust

\begin{tabular}{lll}
\hline Preferences & Politicians & Politicians
\end{tabular}

More selfish, paying more

attention to interest groups, more

impatient

Voters

Want as high aggregate net

benefits as possible, more

impatient

Interest groups

Want as high net benefits for

themselves as possible, more

impatient

Beliefs

Politicians, voters, interest groups

People cannot be trusted, the

People can be trusted (and

market economy is detrimental (to

aggregate and interest-group net
More altruistic (or selfish but more

induced to behave altruistically),

paying more attention to voters,

more patient

Voters

Want as high aggregate net

benefits as possible, more patient

Interest groups

Want as high net benefits for

themselves as possible, more

patient

Politicians, voters, interest groups

politicians will be held

accountable by voters if they 
benefits)

violate their trust), the market

economy is beneficial (to

aggregate net benefits)

High

overcome

obstacles in the

political process

Note: Each setting is described by tendencies, but there are mixtures of preferences, beliefs and abilities in each one. These are not in any case "corner solutions". 
Table 2. Descriptive statistics

\begin{tabular}{|c|c|c|c|}
\hline & Mean & Standard dev. & Observations \\
\hline$\Delta$ judicial area & .073 & 1.132 & 428 \\
\hline$\Delta$ regulatory area & .262 & .683 & 422 \\
\hline Lag judicial area & 6.198 & 1.912 & 428 \\
\hline Lag regulatory area & 6.200 & 1.292 & 423 \\
\hline Log population & 9.143 & 1.538 & 442 \\
\hline Log GDP per capita & 9.473 & .816 & 442 \\
\hline Openness & 81.212 & 57.248 & 442 \\
\hline Presidential & .301 & .459 & 442 \\
\hline Civil autocracy & .081 & .274 & 442 \\
\hline Military dictatorship & .038 & .193 & 442 \\
\hline Social trust & 28.828 & 15.582 & 442 \\
\hline Government ideology & .219 & .294 & 434 \\
\hline Legislature ideology & .179 & .288 & 434 \\
\hline Legislature ideological & .169 & .119 & 434 \\
\hline \multicolumn{4}{|l|}{ fractionalization } \\
\hline Government ideological & .027 & .052 & 435 \\
\hline \multicolumn{4}{|l|}{ fractionalization } \\
\hline Seat instability & .223 & .225 & 428 \\
\hline Minority government & .274 & .446 & 442 \\
\hline Coalition government & .482 & .500 & 442 \\
\hline
\end{tabular}


Table 3. Main results, reforms with government ideology

\begin{tabular}{|c|c|c|c|c|}
\hline \multirow{2}{*}{$\begin{array}{l}\text { Area } \\
\text { Reform } \\
\text { direction }\end{array}$} & \multicolumn{2}{|c|}{$\Delta$ judicial area } & \multicolumn{2}{|c|}{$\Delta$ regulatory area } \\
\hline & Positive & Negative & Positive & Negative \\
\hline Lag area & $-1.795 * * *$ & $.914 * * *$ & $-.674 * * *$ & $.441 * * *$ \\
\hline (judicial or & $(.269)$ & $(.202)$ & $(.211)$ & $(.149)$ \\
\hline \multicolumn{5}{|l|}{ regulatory) } \\
\hline \multirow[t]{2}{*}{ Log population } & -.012 & .074 & -.092 & -.124 \\
\hline & $(.146)$ & (.139) & $(.131)$ & $(.122)$ \\
\hline Log GDP per & $1.656 * * *$ & $-1.137 * * *$ & -.227 & -.032 \\
\hline capita & $(.555)$ & $(.438)$ & $(.436)$ & $(.375)$ \\
\hline \multirow[t]{2}{*}{ Openness } & .179 & -.555 & .026 & $-.924 * *$ \\
\hline & $(.406)$ & $(.418)$ & $(.368)$ & $(.434)$ \\
\hline \multirow[t]{2}{*}{ Minority } & .114 & .092 & $.917 * * *$ & $.894 * * *$ \\
\hline & $(.382)$ & $(.336)$ & $(.352)$ & $(.298)$ \\
\hline \multirow[t]{2}{*}{ Coalition } & -.166 & -.037 & -.015 & .106 \\
\hline & $(.388)$ & $(.335)$ & $(.359)$ & $(.298)$ \\
\hline \multirow[t]{2}{*}{ Presidential } & -.934 & $-1.207 * *$ & $-1.515^{* *}$ & -.373 \\
\hline & $(.594)$ & $(.555)$ & $(.620)$ & $(.406)$ \\
\hline \multirow[t]{2}{*}{ Civil autocracy } & .604 & .567 & .232 & -.172 \\
\hline & $(.941)$ & $(.814)$ & $(.724)$ & $(.719)$ \\
\hline Military & -.795 & -1.033 & -1.506 & -.948 \\
\hline
\end{tabular}




\begin{tabular}{|c|c|c|c|c|}
\hline dictatorship & (1.105) & $(1.035)$ & $(1.265)$ & $(.817)$ \\
\hline \multirow[t]{2}{*}{ Social trust } & $.047 * *$ & $-.037 * *$ & .009 & $-.029 * *$ \\
\hline & (.019) & $(.018)$ & $(.017)$ & $(.014)$ \\
\hline Government & -.221 & .046 & 1.385 & -.573 \\
\hline ideology & (.939) & $(.832)$ & $(.901)$ & $(.648)$ \\
\hline \multirow[t]{2}{*}{ Trust $*$ ideology } & .021 & -.019 & -.013 & .000 \\
\hline & $(.033)$ & $(.030)$ & $(.030)$ & $(.024)$ \\
\hline Time FE & Yes & Yes & Yes & Yes \\
\hline Regional FE & Yes & Yes & Yes & Yes \\
\hline Observations & 327 & 317 & 309 & 314 \\
\hline Countries & 66 & 65 & 65 & 65 \\
\hline Chi squared & -124.476 & -149.556 & -148.595 & -186.838 \\
\hline Log likelihood & 69.16 & 58.21 & 48.14 & 29.96 \\
\hline \multicolumn{5}{|l|}{ Trust effects at } \\
\hline \multirow[t]{2}{*}{$10^{\text {th }}$ percentile } & .037 & -.028 & .015 & -.030 \\
\hline & $(.031)$ & $(.028)$ & $(.027)$ & $(.022)$ \\
\hline \multirow[t]{2}{*}{$25^{\text {th }}$ percentile } & $.047 * *$ & $-.037 * *$ & .009 & $-.029 * *$ \\
\hline & $(.019)$ & $(.018)$ & $(.017)$ & $(.014)$ \\
\hline \multirow[t]{2}{*}{ Median } & $.053 * * *$ & $-.042 * * *$ & .006 & $-.029 * *$ \\
\hline & $(.017)$ & $(.016)$ & $(.015)$ & $(.013)$ \\
\hline $75^{\text {th }}$ percentile & $.058 * * *$ & $-.047 * * *$ & .003 & $-.029 * *$ \\
\hline
\end{tabular}




$\begin{array}{ccccc} & (.018) & (.018) & (.016) & (.014) \\ 90^{\text {th }} \text { percentile } & .064 * * * & -.052 * * & -.000 & -.029 * \\ & (.023) & (.022) & (.021) & (.018)\end{array}$

Note: $* * *(* *)[*]$ denote significance at $\mathrm{p}<.01(\mathrm{p}<.05)[\mathrm{p}<.10]$. Standard errors in parentheses. 
Table 4a. Main results, positive judicial reforms (increasing the quality of the legal system)

\begin{tabular}{|c|c|c|c|c|c|}
\hline Problem & $\begin{array}{l}\text { Legislature } \\
\text { ideology }\end{array}$ & $\begin{array}{l}\text { Ideology } \\
\text { fractionalization }\end{array}$ & $\begin{array}{c}\text { Minority } \\
\text { government }\end{array}$ & $\begin{array}{l}\text { Coalition } \\
\text { government }\end{array}$ & $\begin{array}{c}\text { Seat } \\
\text { instability }\end{array}$ \\
\hline & \multicolumn{5}{|c|}{ Full baseline specification included } \\
\hline Social trust & $.040^{*}$ & .045 & $062 * * *$ & $.048 * *$ & $.057 * * *$ \\
\hline & $(.024)$ & $(.028)$ & $(.022)$ & $(.024)$ & $(.022)$ \\
\hline \multirow[t]{2}{*}{ Problem } & -.81 & -2.404 & .540 & -.384 & -1.645 \\
\hline & (1.438) & (3.223) & $(.775)$ & $(.814)$ & (1.983) \\
\hline Trust * & .048 & .053 & -.014 & .008 & .003 \\
\hline problem & $(.063)$ & $(.115)$ & $(.021)$ & $(.024)$ & $(.083)$ \\
\hline Observations & 327 & 327 & 327 & 327 & 327 \\
\hline Countries & 66 & 66 & 66 & 66 & 66 \\
\hline Chi squared & 69.11 & 69.17 & 69.03 & 69.03 & 67.46 \\
\hline $\log$ & -124.584 & -124.654 & -124.634 & -124.634 & -123.250 \\
\hline \multicolumn{6}{|l|}{ likelihood } \\
\hline \multicolumn{6}{|l|}{ Trust effects } \\
\hline \multicolumn{6}{|l|}{ at } \\
\hline $10^{\text {th }}$ & .026 & .045 & & & $.057 * * *$ \\
\hline percentile & $(.039)$ & $(.028)$ & & & $(.020)$ \\
\hline $25^{\text {th }}$ & $.040^{*}$ & $.047 *$ & $.062 * * *$ & $.048 * *$ & $.057 * * *$ \\
\hline percentile, & $(.024)$ & $(.025)$ & $(.022)$ & $(.024)$ & $(.018)$ \\
\hline
\end{tabular}


single

Median

$.051 * * * \quad .053 * * *$

$.057 * * *$

$(.017)$

$(.018)$

$75^{\text {th }}$

$.056^{* * * *}$

$.057 * * *$

$.056^{* * *}$

$.056^{* * *}$

$.058 * * *$

percentile,

$(.018)$

$(.017)$

$(.018)$

(.018)

$(.022)$

majority,

coalition

$90^{\text {th }}$

$.066^{* * *}$

$.062 * * *$

$.058 *$

percentile

$(.024)$

$(.022)$

Note: $* * *(* *)[*]$ denote significance at $\mathrm{p}<.01(\mathrm{p}<.05)[\mathrm{p}<.10]$. Standard errors in parentheses.

Table 4b. Main results, positive regulatory reforms (decreasing the scope of regulation)

\begin{tabular}{lccccc}
\hline & $\begin{array}{l}\text { Legislature } \\
\text { ideology }\end{array}$ & $\begin{array}{c}\text { Ideology } \\
\text { fractionalization }\end{array}$ & Minority & Coalition & Seat \\
& \multicolumn{5}{c}{ Full baseline specification included } \\
Social trust & .001 & .006 & .018 & $.048^{* *}$ & government \\
& $(.022)$ & $(.026)$ & $(.019)$ & $(.023)$ & $(.019)$ \\
Legislature & 1.327 & -.188 & $1.477^{* *}$ & $1.450^{* *}$ & 1.033 \\
ideology & $(1.359)$ & $(3.063)$ & $(.698)$ & $(.722)$ & $(1.793)$ \\
Trust $*$ & .004 & .041 & -.018 & $-.052^{* *}$ & -.019 \\
ideology & $(.062)$ & $(.103)$ & $(.019)$ & $(.022)$ & $(.073)$ \\
\hline
\end{tabular}




\begin{tabular}{|c|c|c|c|c|c|}
\hline Observations & 309 & 309 & 309 & 309 & 309 \\
\hline Countries & 65 & 65 & 65 & 65 & 65 \\
\hline Chi squared & 46.94 & 45.45 & 61.52 & 63.02 & 59.66 \\
\hline $\log$ & -148.676 & -155.113 & -148.235 & -145.864 & -148.936 \\
\hline \multicolumn{6}{|l|}{ likelihood } \\
\hline \multicolumn{6}{|l|}{ Trust effects } \\
\hline \multicolumn{6}{|l|}{ at } \\
\hline $10^{\text {th }}$ & -.000 & .006 & & & .010 \\
\hline percentile & $(.038)$ & $(.026)$ & & & $(.018)$ \\
\hline $25^{\text {th }}$ & .001 & .007 & .018 & $.048 * *$ & .009 \\
\hline percentile, & $(.022)$ & $(.023)$ & (.019) & $(.023)$ & $(.016)$ \\
\hline \multicolumn{6}{|l|}{ minority, } \\
\hline \multicolumn{6}{|l|}{ single } \\
\hline \multirow[t]{2}{*}{ Median } & .002 & .012 & & & .007 \\
\hline & $(.015)$ & $(.015)$ & & & $(.015)$ \\
\hline $75^{\text {th }}$ & .003 & .016 & -.001 & -.005 & .004 \\
\hline percentile, & $(.016)$ & $(.014)$ & $(.016)$ & $(.016)$ & $(.018)$ \\
\hline \multicolumn{6}{|l|}{ majority, } \\
\hline \multicolumn{6}{|l|}{ coalition } \\
\hline $90^{\text {th }}$ & .004 & .019 & & & .001 \\
\hline percentile & $(.022)$ & $(.018)$ & & & (.029) \\
\hline
\end{tabular}


Table 5a. Main results, negative judicial reforms (decreasing the quality of the legal system)

\begin{tabular}{|c|c|c|c|c|c|}
\hline Problem & $\begin{array}{l}\text { Legislature } \\
\text { ideology }\end{array}$ & $\begin{array}{l}\text { Ideology } \\
\text { fractionalization }\end{array}$ & $\begin{array}{c}\text { Minority } \\
\text { government }\end{array}$ & $\begin{array}{l}\text { Coalition } \\
\text { government }\end{array}$ & $\begin{array}{c}\text { Seat } \\
\text { instability }\end{array}$ \\
\hline & \multicolumn{5}{|c|}{ Full baseline specification included } \\
\hline Social trust & -.022 & $-.049 *$ & $-.043 * *$ & $-.058 * *$ & $-.036^{*}$ \\
\hline & $(.022)$ & $(.026)$ & $(.019)$ & $(.024)$ & $(.019)$ \\
\hline \multirow[t]{2}{*}{ Problem } & 1.003 & .131 & .029 & -.585 & 1.364 \\
\hline & $(1.425)$ & $(2.828)$ & $(.634)$ & $(.696)$ & (1.505) \\
\hline Trust * & -.079 & .031 & .002 & .021 & -.032 \\
\hline problem & $(.062)$ & $(.101)$ & $(.020)$ & $(.023)$ & $(.069)$ \\
\hline Observations & 317 & 317 & 317 & 317 & 317 \\
\hline Countries & 66 & 66 & 65 & 66 & 66 \\
\hline Chi squared & 57.60 & 58.05 & 58.20 & 59.06 & 57.63 \\
\hline $\log$ & -148.881 & -149.963 & -149.754 & -149.345 & -147.085 \\
\hline \multicolumn{6}{|l|}{ likelihood } \\
\hline \multicolumn{6}{|l|}{ Trust effects } \\
\hline \multicolumn{6}{|l|}{ at } \\
\hline $10^{\text {th }}$ & .001 & $-.049 *$ & & & $-.037 *$ \\
\hline percentile & $(.037)$ & $(.026)$ & & & $(.019)$ \\
\hline $25^{\text {th }}$ & -.022 & $-.048 * *$ & $-.043 * *$ & $-.058 * *$ & $-.038 * *$ \\
\hline percentile, & $(.022)$ & $(.023)$ & $(.019)$ & $(.024)$ & $(.017)$ \\
\hline
\end{tabular}


single

Median

$$
-.039 * * \quad-.045 * * *
$$

$-.041 * *$

(.016)

(.017)

(.016)

$75^{\text {th }}$

$-.049 * * *$

$-.042 * *$

$-.041 * *$

$-.037 * *$

$-.046^{* *}$

percentile,

(.018)

(.016)

(.019)

(.017)

(.019)

majority,

coalition

$90^{\text {th }}$

$-.064 * * *$

$-.039 *$

$-.053^{*}$

percentile

(.025)

(.020)

(.029)

Note: $* * *(* *)[*]$ denote significance at $\mathrm{p}<.01(\mathrm{p}<.05)[\mathrm{p}<.10]$. Standard errors in parentheses.

Table 5b. Main results, negative regulatory reforms (increasing the scope of regulation)

\begin{tabular}{lccccc}
\hline & $\begin{array}{l}\text { Legislature } \\
\text { ideology }\end{array}$ & $\begin{array}{c}\text { Ideology } \\
\text { fractionalization }\end{array}$ & Minority & Coalition & Seat \\
& & \multicolumn{2}{c}{ Full baseline specification included } & government & instability \\
Social trust & -.019 & -.021 & $-.039^{* *}$ & $-.064^{* * *}$ & $-.036^{* *}$ \\
& $(.017)$ & $(.023)$ & $(.016)$ & $(.023)$ & $(.016)$ \\
Legislature & -.576 & 2.206 & .417 & -1.048 & .216 \\
ideology & $(1.134)$ & $(2.606)$ & $(.563)$ & $(.638)$ & $(1.473)$ \\
Trust $*$ & -.029 & -.026 & .017 & $.043 * *$ & .023 \\
ideology & $(.049)$ & $(.090)$ & $(.017)$ & $(.022)$ & $(.060)$ \\
\hline
\end{tabular}




\begin{tabular}{|c|c|c|c|c|c|}
\hline Observations & 314 & 314 & 314 & 309 & 314 \\
\hline Countries & 65 & 65 & 65 & 65 & 65 \\
\hline Chi squared & 31.49 & 19.07 & 30.58 & 30.59 & 28.31 \\
\hline $\log$ & -185.669 & -191.875 & -186.339 & -184.601 & -181.778 \\
\hline \multicolumn{6}{|l|}{ likelihood } \\
\hline \multicolumn{6}{|l|}{ Trust effects } \\
\hline \multicolumn{6}{|l|}{$a t$} \\
\hline $10^{\text {th }}$ & -.011 & -.021 & & & $-.036 * *$ \\
\hline percentile & (.029) & $(.023)$ & & & $(.015)$ \\
\hline $25^{\text {th }}$ & -.019 & -.021 & $-.039 * *$ & $-.064 * * *$ & $-.035 * *$ \\
\hline percentile, & $(.017)$ & $(.021)$ & $(.016)$ & $(.023)$ & $(.014)$ \\
\hline \multicolumn{6}{|l|}{ minority, } \\
\hline \multicolumn{6}{|l|}{ single } \\
\hline \multirow[t]{2}{*}{ Median } & $-.026 * *$ & $-.024 *$ & & & $-.033 * * *$ \\
\hline & $(.013)$ & $(.015)$ & & & $(.013)$ \\
\hline $75^{\text {th }}$ & $-.029 * *$ & $-.027 *$ & -.023 & -.021 & $-.029 *$ \\
\hline percentile, & $(.014)$ & $(.014)$ & $(.014)$ & $(.014)$ & $(.016)$ \\
\hline \multicolumn{6}{|l|}{ majority, } \\
\hline \multicolumn{6}{|l|}{ coalition } \\
\hline $90^{\text {th }}$ & $-.035^{*}$ & $-.029 *$ & & & -.024 \\
\hline percentile & (.019) & $(.017)$ & & & $(.025)$ \\
\hline
\end{tabular}

Note: $* * *(* *)[*]$ denote significance at $\mathrm{p}<.01(\mathrm{p}<.05)[\mathrm{p}<.10]$. Standard errors in parentheses. 
Table A1. Countries included

\begin{tabular}{lcclcc}
\hline Countrv & Trust & Ec. freedom & Countrv & Trust & Ec. freedom \\
\hline Albania & 20.66 & $7.34 / .50$ & Jamaica & 37.3 & $6.99 / .5$ \\
Argentina & 19.39 & $5.72 /-.13$ & Japan & 39.59 & $7.6 /-.25$ \\
Australia & 48.01 & $7.9 / .13$ & Korea & 32.22 & $7.48 / .13$ \\
Austria & 37.38 & $7.61 /-.25$ & Latvia & 19.63 & $7.14 / .33$ \\
Belgium & 31.9 & $7.4 /-.25$ & Lithuania & 24.18 & $7.56 / .67$ \\
Belize & 7.45 & $6.71 /-.17$ & Luxembourg & 30.67 & $7.53 /-.38$ \\
Bolivia & 19.25 & $6.39 / 0$ & Macedonia & 10.86 & $6.96 / 0$ \\
Brazil & 5.77 & $6.47 /-.13$ & Malta & 23.64 & $7.57 / 0$ \\
Bulgaria & 27.12 & $7.3 / .20$ & Mexico & 22.74 & $6.70 /-.25$ \\
Canada & 47.73 & $8.05 / 0$ & Montenegro & 30.31 & $7.46 / 1$ \\
Chile & 16.68 & $7.95 / .25$ & Netherlands & 56.32 & $7.46 /-.25$ \\
Colombia & 13.85 & $6.54 /-.13$ & New Zealand & 52.62 & $8.35 / 0$ \\
Costa Rica & 13.47 & $7.32 /-.29$ & Nicaragua & 18.65 & $7.12 / .33$ \\
Croatia & 21.02 & $6.78 / .33$ & Norwav & 66.44 & $7.53 / 0$ \\
Cyprus & 13.54 & $7.75 / 0$ & Panama & 22.25 & $7.20 /-.14$ \\
Czech Rep & 27.01 & $7.21 / .33$ & Paraguav & 9.5 & $6.72 /-.17$ \\
Denmark & 68.08 & $7.89 / .13$ & Peru & 9.66 & $7.6 / .13$ \\
Dominican & 26.45 & $7.12 / 0$ & Poland & 21.3 & $7.13 / .60$ \\
Ecuador & 13.87 & $5.81 / .13$ & Portugal & 19.31 & $7.08 / 0$ \\
El Salvador & 16.38 & $7.1 /-.17$ & Romania & 15.49 & $7.28 / 0$ \\
Estonia & 30.52 & $7.79 / .33$ & Serbia & 18.51 & $6.45 / 0$ \\
Finland & 58.93 & $7.9 /-.13$ & Singapore & 27.98 & $8.73 / 0$ \\
France & 22.98 & $7.42 / 0$ & Slovakia & 19.47 & $7.42 / .33$ \\
Germany & 38.69 & $7.57 /-.25$ & Slovenia & 20.31 & $6.59 / 0$ \\
Greece & 21.57 & $6.94 /-.13$ & Spain & 31.34 & $7.35 /-.13$ \\
Guatemala & 21.5 & $7.20 / .13$ & Sweden & 63.91 & $7.64 / .25$ \\
Guyana & 17.06 & $6.24 / 0$ & Switzerland & 47.1 & $8.31 /-.25$ \\
Haiti & 14.02 & $6.44 /-.33$ & Taiwan & 33.65 & $7.77 / .13$ \\
Honduras & 18.75 & $7.24 / .17$ & Trinidad & 6.19 & $6.93 / .14$ \\
Hungarv & 25.43 & $7.30 / .33$ & Turkev & 9.66 & $6.90 / .38$ \\
Iceland & 45.34 & $7.09 / .13$ & United & 36.45 & $7.82 / 0$ \\
Ireland & 39.03 & $7.62 / 0$ & United States & 40.45 & $7.74 /-.25$ \\
Israel & 23.46 & $7.30 / .13$ & Uruguav & 24.91 & $7.34 / 0$ \\
Italy & 29.65 & $6.83 / 0$ & Venezuela & 14.11 & $3.98 /-.63$ \\
\hline Thesecond & 19.96 &
\end{tabular}

The second figure in the economic freedom column refers to the average change across the

full period. 
Fig. 1. Net benefits as a function of economic freedom

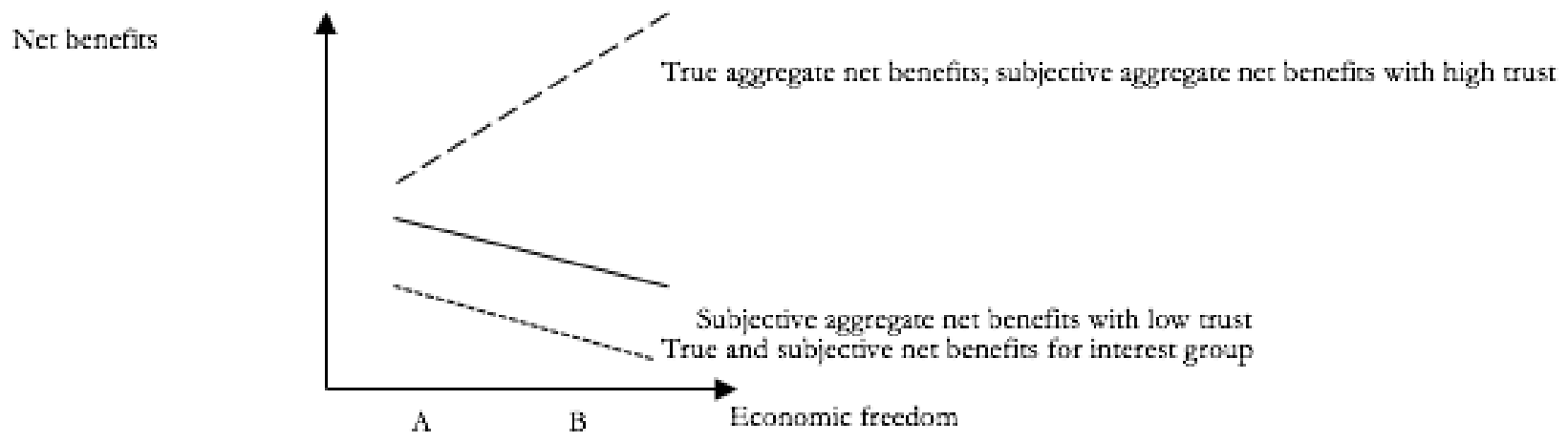


Fig. 2. Ratio of positive to negative reforms for area 2 of the EFW (legal quality), high and low-trust countries

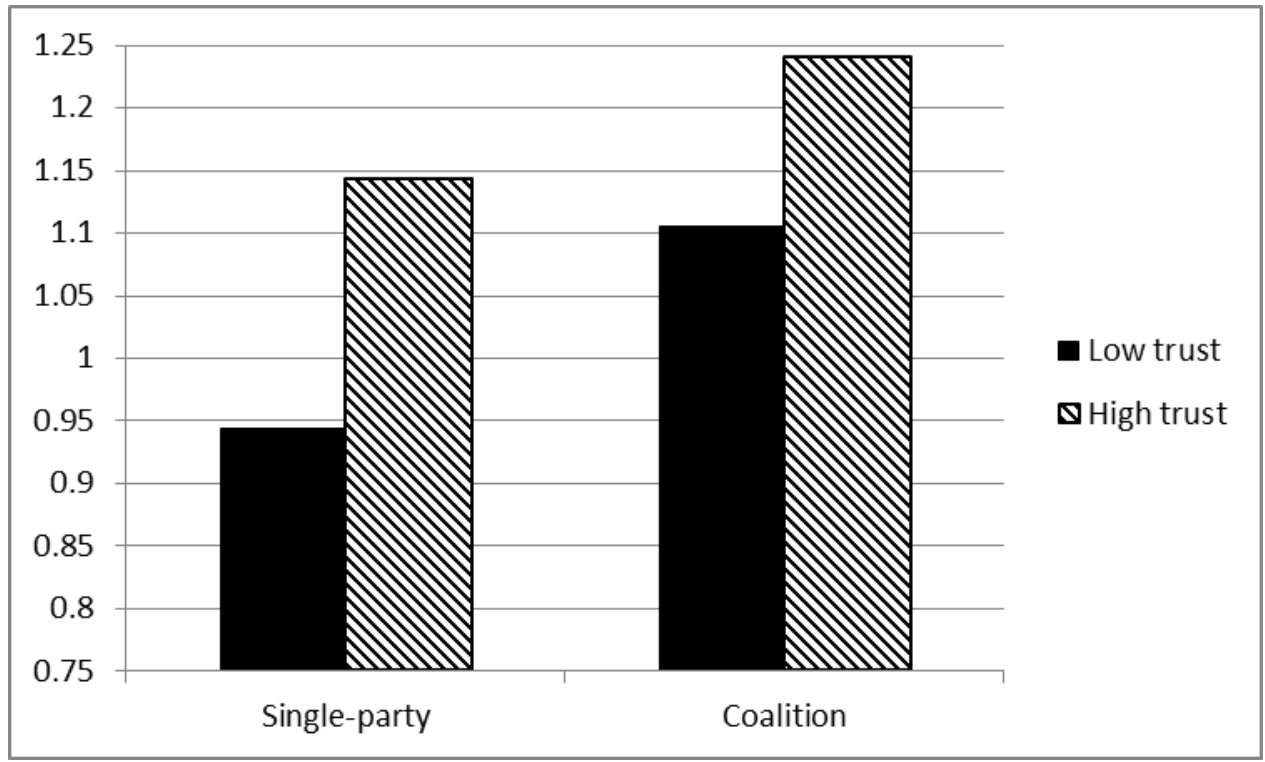

